\title{
Opportunity for the Operation of Natural Selection in a Contemporary Local Population (The Case of Slovincians, Poland)
}

\author{
Oskar Nowak ${ }^{1}$, Grażyna Liczbińska ${ }^{2 *}$, Janusz Piontek ${ }^{1}$ \\ ${ }^{1}$ Department of Human Evolutionary Biology, Faculty of Biology, Institute of Anthropology, \\ Adam Mickiewicz University, Poznań, Poland \\ ${ }^{2}$ Department of Human Population Ecology, Faculty of Biology, Institute of Anthropology, \\ Adam Mickiewicz University, Poznań, Poland \\ Email: oskarn@amu.edu.pl, "grazyna@amu.edu.pl
}

Received February 19 th $^{\text {th }}$ 2013; revised March $19^{\text {th }}, 2013$; accepted March $29^{\text {th }}, 2013$

Copyright (C) 2013 Oskar Nowak et al. This is an open access article distributed under the Creative Commons Attribution License, which permits unrestricted use, distribution, and reproduction in any medium, provided the original work is properly cited.

\begin{abstract}
In research practice, it is possible to observe natural selection at work by analysing fertility and mortality. Crow's index takes into account both of these vital statistics components and allows a quantitative estimation of the operation of natural selection on the basis of demographic birth and death figures. In this study, we use the classical Crow's index to determine whether the disintegration of the Slovincian population in the second half of the 20th century was caused by factors of a biological nature, finally leading to disturbances in the reproductive strategy, or whether it was a result of the impact of many factors of a cultural nature. Use was made of measuring cards for 109 women and 38 men. The sample was divided into two generations: 1st generation, or individuals born up to the year 1900, and 2nd generation - those born after 1900. In this material the opportunity for the operation of natural selection due to differential mortality and differential fertility was rather weak. Both generations of Slovincians were characterized by high fertility, suggesting their non-Malthusian type of reproductive strategy, and decreasing mortality of sexually immatures over time.It seems, therefore, that the loss of ethnic identity by Slovincians and their migration from the home territories was influenced by several factors of a cultural nature rather than their biological distinctness.
\end{abstract}

Keywords: Crow's Index; Mortality; Fertility; Ecology; Ethnicity; Disintegration

\section{Introduction}

Natural selection is the main factor of the evolutionary process. This factor still operates in contemporary populations, causing slow gradual evolutionary changes (e.g. Byars et al., 2010; Kosova et al., 2010; Little et al., 1989, 2008; Malina et al., 2008; Prakash \& Narayanan, 2009). A measure of the operation of natural selection is diversity in the reproductive success of individuals. In research practice, it is possible to observe natural selection at work on the basis of the analysis of fertility and mortality in populations (Piontek, 1979; Prakash \& Narayanan, 2009).

The index of total selection intensity proposed by Crow (1958) combines both vital-statistics components and allows estimating the intensity of selection by differential mortality and differential fertility. The first component of Crow's index takes into account only the mortality of individuals who do not reached sexual maturity (Crow, 1958), and determines the proportion of children who failed to live to reproductive age to those who attained it. The other component takes into account the opportunity for natural selection due to differential fertility and is estimated by the ratio of the variance of the number of children in complete families (i.e. with wives past their childbearing age) to the square mean of the number of children in

"Corresponding author. those families (Crow, 1958; Piontek, 1979). The original Crow's index has seen some modifications. Since it covered mortality at postnatal age only, Johnston and Kensinger (1971) introduced into its formula a correction for prenatal mortality. Brena and Martinez $(1986,1987)$, in turn, set the interpretation of Crow's index in an evolutionary context.

In anthropology, and in particular in the biology of historical populations (studied on the basis of archival research) and prehistoric populations (studied on the basis of skeletal remains), Crow's index is a very popular measure. Despite some limitations (its $\mathrm{I}_{\mathrm{m}}$ component does not include the mortality of adults, and the $I_{f}$ component takes into account the total number of offspring about which we are not sure whether or not it is regulated culturally), it is widely used in research because it allows a quantitative estimation of the operation of natural selection on the basis of the demographic statistics of births and deaths, often collected during anthropological studies (Jorde \& Durbize, 1986, Terrenato et al., 1979; Hed, 1984, 1987; Reddy \& Chopra, 1990).

Spuhler (1963, 1976), for example, analysed the values of Crow's index for 57 populations of the world and stressed that they varied in different regions as a reflection of their ecological and cultural conditions. With regard to the populations of the former Soviet Union, a spatial variation of Crow's index was studied (Bolshakova \& Revazov, 1988; Ivanov et al., 1997; 
Kadoshnikova et al., 1996; Kucher \& Soltobaeva, 2004; Kurbatowa et al., 2005; Posukh et al., 1996; Revazov \& Bolshakova, 1984; Startseva et al., 1996). The same was true of the highly endogamous and isolated mountain communities of India (e.g. Dharani et al., 2003; Chanu \& Varte, 2009; Lakshmi et al., 2005; Rajanikumari et al., 1985; Reddy et al., 1987, 1990; Varte \& Varte, 2006), the Yanomama Indians (Neel \& Weiss, 1975), or some European populations, such as Swedish (Hed, 1984, 1987) and Spanish (Alfonso-Sánches et al., 2004; Blanco Villefas \& Fuster, 2007; Luna \& Moral, 1990).

With regard to the populations from the Polish territory, the opportunity for natural selection has been a subject of many studies, both of prehistoric populations as historical ones (e.g. Budnik, 2005; Budnik \& Liczbińska, 2006; Budnik \& Przybyszewska, 1991; Budnik et al., 2002, 2004; Berdychowski \& Henneberg, 1978; Hennenberg \& Piontek, 1975; Henneberg et al., 1977; Liczbińska, 1999, 2009, 2011; Nowak et al., 2011a, 2011b; Piontek, 1979; Piontek \& Krenz, 1994; Wrzesińska \& Wrzesiński, 2002). In particular, researchers have focused on measures of the opportunity for natural selection by differential mortality, which in prehistoric and historical populations was an excellent reflection of ecological conditions (e.g. Budnik, 2005; Henneberg, 1977; Liczbińska, 2009, 2011; Nowak et al., 2009, 2011a, 2011b; Piontek, 1979; Piontek \& Krenz, 1994; Puch, 1993). It is highly interesting to analyse differential fertility and differential mortality in indigenous groups which ceased to exist at a certain moment. One of such groups on the contemporary Polish territory was Slovincians, regarded by some scholars and researchers as a subpopulation of Kashubians.

In this paper, using the classical Crow's index, we want to determine whether the disintegration of Slovincians was caused by biological (environmental and adaptive) factors finally leading to disturbances in their reproductive strategy, or if it was perhaps the impact of cultural (and/or political) factors which caused them to lose their ethnic identity and migrate from the home territory. Our study is a contribution to the understanding of the biological history of "small nations" of Europe which accelerates the processes of acculturation and disintegration.

\section{Materials and Methods}

\section{Characteristics of the Slovincians Population}

From the ethnographic point of view, Slovincians are a distinct ethnic group that used to inhabit the area between Lakes Gardno and Łebsko (Figure 1), from the late 18th century to the early 20th century surrounded by German settlements. Some researchers, for example Witt (1933), argue that in the past Slovincians could stand for a separate tribal group. On the basis of his research conducted in the area of Smołdzino (Figure 1), Witt (1933) claimed that the local Rowokó hills could be the locality of some prehistoric native ethnic group. His opinion was corroborated by archaeological findings. This point of view was also supported by Łęga (1930), who located the Slovincian tribes in Western Pomerania.

Linguists have included Slovincians into the ethno-cultural group which was part of the Kashubian population. Studies of the dialects of the Pomeranian language have shown a very close similarity between the Slovincian and Kashubian dialects. Hilferding (1989) and Lorentz (1908-1912) placed Slovincian in the Kashubian language group, and included the population of Slovincians into indigenous Kashubians living in the past on the territory between Lakes Gardno and Łebsko. The village of
Kluki (Figure 1), where once lived the majority of Slovincians, was originally established from three separate settlements: Kluki Smołdzińskie, Kluki Żelewskie, and Kluki Ciemińskie. The fragmentary ethnographic research conducted among Slovincians in the 19th century shows that they considered themselves Kashubians of the Protestant denomination, in contrast to Kashubian Catholics, determined by the synonym of "Poles" (Stelmachowska, 1963).

During the period of partitions, there took place a process of denationalization of local territories, causing not only a decrease in the population of Slovincians, but also a disappearance of their dialect. At the end of the 19th century only about 30 villages remained here (Dejna, 1973). After World War II, several hundred Slovincians survived, and in the 1950s a little over a hundred left Pomerania (Filip, 2012; Ostrowska \& Trojanowska, 1978). The meeting of Poles coming from the east with highly Germanized Slovincians demanding from the Polish authorities a permission to leave for Germany, ended in failure. Some of them left Pomerania in the 1950s and 1960s under the "family reunification" programme, and the last outflow of Slovincians to Germany occurred in the 1970s. At that time 122 people left the above-mentioned village of Kluki, including 57 mixed families.

\section{Material}

Use was made of the material deposited in the archives of the Institute of Anthropology at Adam Mickiewicz University in Poznań. It was collected in the 1950s by Professor Franciszek Wokroj (1958, 1960), who conducted systematic anthropological studies of populations inhabiting the territory between the rivers Łeba and Gardna Wielka. From the measuring cards containing anthropometric data and the questionnaire, the following information was used: date and place of birth of respondents, place of residence, number of siblings, number of siblings who died before reaching the age of 14 , and total number of children in families. A total of 147 individuals were examined, including 109 women and 38 men.

\section{Methods}

The research material was divided into two generations. A turning point was the year 1900. The first generation encompassed all individuals born up to 1900, and the second one, those born after 1900. The opportunity for natural selection was calculated using the classical Crow's index (1958). As is known, this index has two components: an index of opportunity for natural selection through differential mortality $\mathrm{I}_{\mathrm{m}}$, and an index of opportunity for natural selection through differential fertility $I_{f}$, and is calculated according to the following formula:

$$
\mathrm{I}=\mathrm{I}_{\mathrm{m}}+\mathrm{I}_{\mathrm{f}}
$$

in this formula $I_{m}=P_{d} / P_{s}$, where:

$\mathrm{P}_{\mathrm{d}}$ : proportion of offspring deceased before reaching reproductive age, which is 14 years; and

$\mathrm{P}_{\mathrm{s}}$ : proportion of offspring reaching reproductive age $\left(\mathrm{P}_{\mathrm{s}}=1-\mathrm{P}_{\mathrm{d}}\right)$.

The second component of Crow's index measures the opportunity for natural selection through differential fertility $\mathrm{I}_{\mathrm{f}}$, and is calculated according to the formula:

$$
I_{f}=\frac{V_{f}}{x^{2}} \text {, where, }
$$

where $V_{f}$ is the variance of the number of offspring in complete 


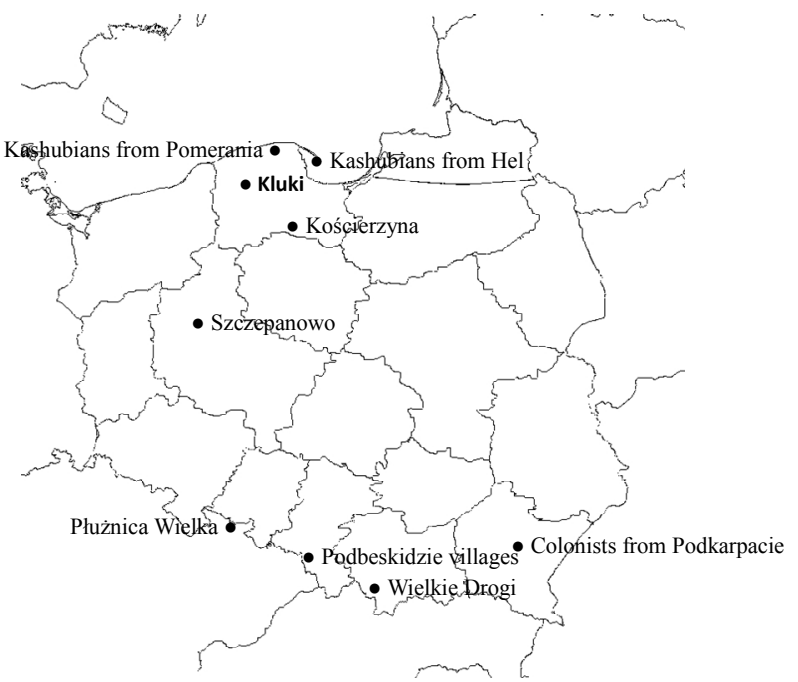

Figure 1.

Slovincian territories (with the village of Kluki) against the populations of historical and contemporary Poland.

families and $x^{2}$ : the square of the arithmetic mean of the number of offspring in those families.

The results were compared with data drawn from the literature for selected populations of historical and contemporary Poland and Europe.

\section{Results and Discussion}

The values of $I_{m}, I_{f}$, and of the index of total selection intensity calculated for both generations: that born up to 1900 and at the beginning of the 20th century, are presented in Table 1. What is striking is the significant difference in the $I_{m}$ values between the two generations: higher in that born in the 19th century than in the group born after 1900. It was confirmed by the proportion of offspring deceased before reaching reproductive age $P_{d}\left(d_{0-14}\right.$; Table 1). A similar trend was observed at that time in Pomerania (Budnik, 2005; Liczbińska, 1999, 2005). Among individuals born in the late 19th century (1st generation), up to $31 \%$ of infants and young children did not live to reproductive age, while in the next generation this proportion fell by half (Table 1). In the 19th century the high mortality rate of children reflected poor environmental conditions and a very low level of medical care. Similarly high values of the $I_{m}$ index were noted in rural populations of historical Polish territories and Europe (Table 2). In the 19th century the value of Crow's index due to differential mortality ranged from slightly below 1, as in Szczepanowo in Greater Poland (Henneberg, 1980), to much above 1 , as in the rural parish of Płużnica Wielka in Silesia (the former Duchy of Prussia; Puch, 1993), or the village of Wielkie Drogi in Little Poland (Puch, 1993; Table 2). In the 19th and early 20th centuries, infant and child mortality was lower in villages than in urban centres, which was reflected in the stratification of the values of Crow's index in favour of rural areas. In the Catholic parish of St. Margaret in the city of Poznan $I_{m}$ was higher than in the villages of Płużnica Wielka and Wielkie Drogi, though it was very high in them too (Liczbińska, 2011; Puch, 1993). In the 1950s and 1960s this trend was reversed (Table 2). Generally speaking, along with the improvement of sanitation, epidemiological conditions and medical care that accompanied Central Europe's entrance into the second stage of demographic and epidemiological transition, the values of $I_{m}$ index gradually decreased (Table 2). In the populations of the $1980 \mathrm{~s}$ and $1990 \mathrm{~s}, \mathrm{I}_{\mathrm{m}}$ values range from 0.06 to 0.29, which should not be surprising (Table 2; Budnik, 1996; Berdychowski \& Henneberg, 1978; Nowak et al., 2011a, 2011b; Bolshakova \& Revasov, 1988). The same was true for Slovincians: here $I_{m}$ fell by half over two generations because, as was mentioned earlier, the proportion of deceased infants and young children dropped almost by a half (Table 1).

In turn, the index of the opportunity for natural selection by differential fertility proposed by Crow (1958) is the ratio of the variance of the number of children in families to the square mean number of live births. This index does not take into account the fertility of women who die before the end of their reproductive cycle, but only those with a completed reproduction cycle. As was mentioned earlier, the $\mathrm{I}_{\mathrm{f}}$ index does not allow separating differences in the number of offspring resulting from the genetic background from that culturally modified. In both generations of Slovincians there are no differences in the $\mathrm{I}_{\mathrm{f}}$ value, probably due to the lack of birth control in those groups. Although both generations had some knowledge of birth control methods and agents, they did not use them consciously nor planned the number of children in a family in advance. The same was true in 19th-century Szczepanowo (Henneberg, 1980) as well as Sub-Beskid and Sub-Carpathian villages from the first half of the 20th century (Nowak et al., 2011a, 2011b), Little Poland populations of the 1980s (Budnik \& Przybyszewska, 1991), and Kashubians in the 1990s (Budnik, 1996; Berdychowski \& Henneberg, 1978). The European populations from the comparable period presented in Table 2 generally did not differ from Slovincians in terms of the $I_{\mathrm{f}}$ value, which ranged from 0.28 (agricultural Camprodon; Torrejon \& Bertranpetit, 1987) to slightly over 0.5 (the rural population of Lanciego; Alfonso-Sanchez et al., 2004). An exception was the Swiss population of the 1960s (Spuhler, 1963). Here the $I_{f}$ value exceeded 1. Higher $I_{\mathrm{f}}$ figures were also noted in the rural population of Pinega (the former Soviet Union; Bolshakova \& Revasov, 1988) and in the French populations of the 1960s (Jacquard, 1974) (Table 2). A high value of $I_{f}$ in these populations was probably due to differential fertility resulting from the use of the methods and agents of birth control.

Generally speaking, in the studied Slovincians the operation of the opportunity for natural selection as measured by the classical Crow's index was weak. This applies to both the selection due to differential mortality and due to differential fertility. Slovincians had poor birth control, suggesting a non-Malthu-

Table 1.

Distribution of the number of offspring in complete families, the proportion of deceased, and the values of Crow's index in the studied population.

\begin{tabular}{ccccccccccc}
\hline Generation & $\mathrm{N}$ & $\mathrm{x}$ & $\mathrm{SD}$ & $\mathrm{P}_{\mathrm{d}}$ & $\mathrm{P}_{\mathrm{s}}$ & $\mathrm{V}_{\mathrm{f}}$ & $\mathrm{x}^{2}$ & $\mathrm{I}_{\mathrm{m}}$ & $\mathrm{I}_{\mathrm{f}}$ & $\mathrm{I}$ \\
\hline 1st generation & 32 & 6.75 & 2.78 & 0.31 & 0.66 & 7.93 & 62.88 & 0.46 & 0.17 & 0.63 \\
2nd generation & 116 & 6.02 & 2.82 & 0.17 & 0.82 & 7.74 & 59.90 & 0.21 & 0.22 & 0.43 \\
\hline
\end{tabular}


O. NOWAK ET AL.

Table 2.

Values of Crow's index in the populations of historical and contemporary Poland and Europe.

\begin{tabular}{|c|c|c|c|c|c|c|}
\hline Population & Type of population & Period & $\mathrm{I}_{\mathrm{m}}$ & $\mathrm{I}_{\mathrm{f}}$ & I & Source \\
\hline Maragateria & agricultural & 1900 & 0.22 & 0.47 & 0.80 & Bernis, 1974 \\
\hline Camprodon & agricultural & 1900 & 0.04 & 0,28 & 0.33 & Torrejon \& Bertranpetit, 1987 \\
\hline Szczepanowo & rural & $1865-1874$ & 0.75 & 0.26 & 1.01 & Henneberg, 1978 \\
\hline Płużnica Wielka & rural & $1765-1899$ & $1.66^{1}$ & 0.14 & 1.80 & Puch, 1993 \\
\hline Wielkie Drogi & rural & $1765-1899$ & $1.31^{1}$ & 0.13 & 1.44 & Puch, 1993 \\
\hline Sub-Carpathian villages & rural & $1^{\text {st }}$ half of $20^{\text {th }} \mathrm{c}$ & 0.41 & 0.23 & 0.64 & Nowak et al., 2011a \\
\hline Sub-Beskid colonists & rural & $20^{\text {th }} \mathrm{c}$. & 0.06 & 0.25 & 0.31 & Nowak et al., 2011b \\
\hline Kościerzyna & rural & $1970 \mathrm{~s}$ & 0.11 & 0.25 & 0.36 & Berdychowski \& Henneberg, 1978 \\
\hline Wielkie Drogi & rural & $1980 \mathrm{~s}$ & 0.15 & 0.27 & 0.46 & Jóźwiak, 1984 \\
\hline Kashubians, Hel Peninsula & rural & $1990 \mathrm{~s}$ & 0.29 & 0.09 & 0.38 & Budnik, 1996 \\
\hline Kashubians, Pomerania & rural & $1990 \mathrm{~s}$ & 0.08 & 0.17 & 0.26 & Budnik,1996 \\
\hline Lanciego & rural & $1890-1949$ & 0.22 & 0.52 & 0.87 & Alfonso-Sanchez et al., 2004 \\
\hline Poznań, Catholics & urban & $1855-1866$ & 1.96 & - & - & Liczbińska, 2011 \\
\hline Galich & urban & $1980 \mathrm{~s}$ & 0.10 & 0.37 & 0.52 & Bolshakova \& Revasov, 1988 \\
\hline Sharia & urban & $1980 \mathrm{~s}$ & 0.11 & 0.36 & 0.51 & Bolshakova \& Revasov, 1988 \\
\hline France & Urban + rural & 1900 & 0.26 & 0.84 & 1.32 & Jacquard, 1974 \\
\hline Switzerland & Urban + rural & $1900-1950$ & 0.06 & 1.59 & 1.65 & Spuhler, 1963 \\
\hline Wologoda & rural & $1980 \mathrm{~s}$ & 0.53 & 0.35 & 0.60 & Bolshakova \& Revasov, 1988 \\
\hline Pinega & rural & $1980 \mathrm{~s}$ & 0.19 & 0.82 & 1.79 & Bolshakova \& Revasov, 1988 \\
\hline
\end{tabular}

sian nature of their fertility, and a decline in the mortality of immature individuals over time. Therefore we have no reason to think there was a specific direction in which natural selection operated in the studied population. It rather appears that the main role in the gradual blur of the Slovincian identity and their migration to Germany was played by many factors of a cultural nature, present in the population already before World War I.

\section{Conclusion}

In the summary we want to stress that the anthropological data used in this study were sparse. Therefore the biological dynamics described in this paper could differ slightly from the factual state. In addition, it is worth emphasizing certain limitations posed by Crow's index, which we are aware of.

Despite the above reservations, the following conclusions emerge from our study:

1) Slovincians were characterized by high fertility rates and the related poor birth control, which points to the non-Malthusian character of this population.

2) In the studied population there was a decrease in infant and child mortality over time reflecting an improvement in ecological conditions and medical care in the region.

3) The total selection intensity was very weak and did not differ from that noted in the other regions of Poland and Europe.
4) It seems, therefore, that the loss of ethnic identity by Slovincians and their migration from the home territories was due to the impact of many factors of a socio-political and an economic nature rather than to their biological distinctness resulting from a gene pool different from that in other areas of Poland and Europe.

\section{REFERENCES}

Alfonso-Sanchez, M. A., Calderon, R., \& Peňa J. A. (2004). Opportunity for natural selection in a Basque population and its secular trend: evolutionary implications of epidemic mortality. Human Biology, 76, 361-381. doi:10.1353/hub.2004.0041

Bernis, C. (1974). Estudio biodemográfico de la población maragata. PhD Dissertation. Madrid: University Complutense.

Blanco Villegas, M. J., \& Fuster, V. (2007). Differential reproductive pattern in a rural Spanish region (La Cabrera, Leỏn): Consequences for potential natural selection. Annals of Human Biology, 34, 664672. doi:10.1080/03014460701654349

Berdychowski, W., \& Henneberg, M. (1978). Wstępna ocena stanu biologicznego ludności wiejskiej z okolic Kościerzyny na podstawie wybranych danych o ruchu naturalnym i wędrówkowym. Przegląd Antropologiczny, 44, 53-65.

Bolshakova, L. P., \& Revasov, A. A. (1988). Heritability of fertility in human populations and the structure of the Crow index. Genetika, 24, 340-349.

Brena, J. G., \& Martinez, C. P. (1986, 1987). Relative influence of natural selection and genetic drift, along 104 years, on a population 
in Caceres Province (Spain). Antropologia Portugalesa, 4-5, 191199.

Budnik, A. (1996). Kaszubi polscy a wybrane populacje europejskieGenetyczne podobieństwa i różnice. Przegląd Antropologiczny, 59, 31-43.

Budnik, A. (2005). Uwarunkowania stanu i dynamiki biologicznej populacji kaszubskich w Polsce. Studium antropologiczne. Poznań: Wydawnictwo Naukowe UAM.

Budnik, A., Gumna, I., \& Liczbińska, G. (2002). The biological dynamics of 19th century village populations from the parish of Dziekanowice as a result of the social and political situation in the microregion of Ostrów Lednicki in the early Middle Ages. Studia Lednickie, 7, 95-110.

Budnik, A., \& Liczbińska, G. (2006). Urban and rural differences in mortality and causes of death in historical Poland. American Journal of Physical Anthropology, 129, 294-304. doi:10.1002/ajpa.20288

Budnik, A., Liczbińska, G., \& Gumna, I.(2004). Demographic trends and biological status of historic populations from central Poland: The ostrów lednicki microregion. American Journal of Physical Anthropology, 125, 369-381. doi:10.1002/ajpa.10272

Budnik, A., \& Przybyszewska, M. (1991). Genetic description of the population of Wielkie Drogi village-A apecific case mating distances distribution. Variability and Evolution, 1, 95-103.

Byars, S. G., Ewbank. D., Govindaraju, D. R., \& Stearns, S. C. (2010) Colloquium papers: Natural selection in a contemporary human population. Proceedings of the National Academy of Sciences of the USA, 107, 1787-1792.

Chanu, T. J., \& Varte, R. Th. (2009). Opportunity for natural selection among chakesang of Nagaland, India. Anthropologist, 11, 59-60.

Crow, J. F. (1958). Some possibilities for measuring selection intensities in man. Human Biology, 30, 3-13.

Dejna, K. (1973). Dialekty polskie. Wrocław: Zakład Narodowy im. Ossolińskich.

Dharani P. B., Veerraju, P., \& Venkateswara Rao, T. (2003). Selection intensity among Kshatriyas an endogamous population of Andhra Pradesh. Indian Journal of Human Genetics, 9, 69-73.

Filip, M. (2012). Od Kaszubów do Niemców. Trwanie i zmiana tożsamości Słowińców $w$ perspektywie antropologicznej. PhD Dissertation. Poznań: Adam Mickiewicz University.

Hed, H. (1984). Opportunity for Selection during the 17th-19th Centuries in the Diocese of Linköping as Estimated with Crow's Index in a Population of Clergymen's Wives. Human Heredity, 34, 378-387. doi:10.1159/000153499

Hed, H. M. (1987). Trend in Opportunity for natural Selection in the Swedish population during the period 1650-1980. Human Heredity, 59, 785-797.

Henneberg, M. (1977). Ocena dynamiki biologicznej wielkopolskiej dziewiętnastowiecznej populacji wiejskiej. I. Ogólna charakterystyka demograficzna. Przegląd Antropologiczny, 43, 67-89.

Henneberg, M. (1978). Ocena dynamiki biologicznej wielkopolskiej dziewiętnastowiecznej populacji wiejskiej. III. Opis stanu puli genów na podstawie danych demograficznych. Przeglad Antropologiczny, 44, 33-52.

Henneberg, M. (1980). Intensywność działania doboru naturalnego przez różnicową płodność w populacjach ludzkich-Ocena ilościowa. Przegląd Antropologiczny, 46, 21-60.

Henneberg, M., \& Piontek, J. (1975). Biological state index of human groups. Przeglad Antropologiczny, 41, 191-201.

Henneberg, M., Piontek, J., \& Strzałko, J. (1977). Natural selection and morphological variability: The case of Europe from neolithic to modern times. Current Anthropology, 71, 1349-1352.

Hilferding, A. (1989). Resztki Stowian na poludniowym wybrzeżu morza battyckiego. Gdańsk: Zrzeszenie Kaszubsko-Pomrskie.

Ivanov, V. P., Churnosov, M. I., \& Kirilenko, A. I. (1997). Selection intensity in the population of the Kursk Oblast. Genetika, 33, 1438-1440.

Jacquard, A. (1974). Genetique des populations humaines. Paris: Universitaires de France. doi:10.1007/978-3-642-88415-3

Johnston, F. E., \& Kensinger, K. M. (1971). Fertility and mortality differentials and their implications for microevolutionary change among Cashinahua. Human Biology, 43, 356-364.

Jorde, L. B., \& Durbize, P. (1986). Opportunity for natural selection in the Utah Mormons. Human Biology, 58, 97-114.

Jóźwiak, M. (1984). Charakterystyka rozrodu i sposobności do działania doboru naturalnego wśród ludności wsi Wielkie Drogi (woj. krakowskie). Przegląd Antropologiczny, 50, 316-323.

Kadoshnikova, M. Yu., Brusintseva, O. V., Startseva, E. A., Elchinova, G. I., Petrova, N. V., Bukina, A. M., Mamedova, A. R., \& Ginter, E. K. (1996). Genetic Demographic Peculiarities of the Population of Three Raions of Bryanskaya Oblast. Genetika, 32,1142-1147.

Kosova, G., Abney, M., \& Ober, C. (2010) Colloquium papers: Heritability of reproductive fitness traits in a human population. Proceedings of the National Academy of Sciences of the USA, 107, 17721778 .

Kucher, A. N., \& Soltobaeva, Zh., O. (2004). Genetic demographic structure of rural populations of Kyrgyzstan. Russian Journal of Genetics, 40, 1540-1548.

Kurbatova, O. L., Pobedonostseva, E. Y., \& Privalova, V. A. (2005). Strategies of adaptation: Interpretation selection differences. Journal of Physical Anthropology and Applied Human Sciences, 24, 363-365. doi: $10.2114 /$ jpa. 24.363

Lakshmi, N., Venkateswara Rao, T., \& Veerraju, P. (2005). Opportunity for natural selection among three endogamous subpopulations of Andhra Pradesh. Indian Journal of Human Genetics, 11, 39-43. doi:10.4103/0971-6866.16294

Liczbińska, G. (1999). Biological and social reason of child mortality in the Danzig district in the second half of the 19th century. Anthropological Review, 62, 85-92.

Liczbińska, G. (2005). Biologiczne i społeczne przyczyny umieralności dzieci w rejencji gdańskiej w II połowie XIX wieku. Stupskie Prace Biologiczne, 1, 93-100.

Liczbińska, G. (2009). Infant and child mortality among Catholics and Lutherans in nineteenth century Poznań. Journal of Biosocial Science, 41, 661-683. doi:10.1017/S0021932009990101

Liczbińska, G. (2011). Ecological conditions vs. religious denomination. Mortality among Catholics and Lutherans in nineteenth-century Poznań. Human Ecology, 39, 795-806. doi:10.1007/s10745-011-9428-5

Little, B. B., Malina, R. M., Buschang, P. H., \& Little, L. R. (1989). Natural selection is not related to reduce body size in rural subsistence agricultural community in southern Mexico. Human Biology, 61, 287-296.

Little, B. B., Malina, R. M., \& Peňa Reyes, M. E. (2008). Natural Selection and demographic transition in a Zapotec-speaking genetic isolate in the Valley of Oaxaca, southern Mexico. American Journal of Physical Anthropology, 35, 34-49.

Lorentz, F. (1908-1912). Slovinzisches Wörterbuch, II. St.Petersburg: Kaiserliche Akademie der Wissenschaften.

Luna, F., \& Moral, P. (1990). Mechanisms of natural selection in human rural populations, survey of a Mediterranean region (La Alpujarra, Spain). Annals of Human Biology, 17, 153-158. doi:10.1080/03014469000000902

Łęga, W. (1930). Kultura Pomorza we wczesnym średniowieczu na podstawie wykopalisk. Toruń: Nakładem Towarzystwa Naukowego.

Malina, R. M., Peňa Reyes, M. E., \& Little, B. B. (2008). Epidemiologic Transition in an Isolated Indigenous Community in the Valley of Oaxaca, Mexico. American Journal of Physical Anthropology, 137, 69-81. doi:10.1002/ajpa.20847

Neel, J. V., \& Weiss, K. M. (1975). The genetic structure of a tribal population, the Yanomama Indians. XII. Biodemographic studies. American Journal of Physical Anthropology, 42, 25-51. doi:10.1002/ajpa.1330420105

Nowak, O., Piontek, J., \& Rewekant, A. (2009). Opportunity for natural selection in the rural population of Podbereżce (Ukraine) in the 19th and 20th centuries. Anthropologie, 47, 96-102.

Nowak, O., Piontek, J., \& Zadarko-Domaradzka, M. (2011a). Intergenerational Changes in the Biological Dynamics of Populations from Southern Poland in the 20th Century. Journal of Human Ecology, 33, 11-15.

Nowak, O., Piontek, J., \& Kozłowska, J. (2011b). Biological Condition 
of German Colonists in the Sub-Carpathian Region in the First Half of the 20th Century. The Anthropologist, 13, 195-200.

Ostrowska, R., \& Trojanowska, I. (1978). Bedeker Kaszubski. Gdańsk: Wydawnictwo Morskie.

Piontek, J. (1979). Procesy mikroewolucyjne $w$ europejskich populacjach ludzkich. Poznań: Wydawnictwo UAM.

Piontek, J., \& Krenz, M. (1994). The opportunity for natural selection in a contemporary population from Sidi-Bel-Abbás. Variability and Evolution, 4, 103-108.

Posukh, O. L., Osipova, L. P., Kriukov, I. A., \& Ivakin, E. A. (1996). Genetic-demographic analysis of the population of native inhabitants of the Samburg tundra. Genetika, 32, 822-829,

Prakash, D. S. R. S., \& Narayanan. (2009). Opportunity for natural selection in Yerukula tribe of coastal andhra pradesh. Studies of Tribes and Tribals, 7, 67-69.

Puch, E. A. (1993). Dynamika biologiczna polskich społeczności wiejskich z różnych systemów społeczno-kulturowych w XVIII i XIX wieku. Przeglad Antropologiczny, 56, 5-36.

Rajanikumari, J., Sricumari, C. R., \& Rao, T. V. (1985). Variability of selection opportunities with changing sociocultural environments. Human Heredity, 35, 218-222. doi:10.1159/000153548

Reddy, B. M., \& Chopra, V. P. (1990). Occupation and the opportunity for natural selection: The Indian case. International Journal of Anthropology, 5, 295-308.

Reddy, B. M., Chopra, V. P., \& Malhotra, K. C. (1987). Opportunity for natural selection with reference to population structural measures among the Vadde. Annals of Human Biology, 14, 249-261. doi:10.1080/03014468700009011

Reddy, B. M., Chopra, V. P., \& Malhotra, K. C. (1990). Opportunity for natural selection among the Indian populations. American Journal of Physical Anthropology, 83, 281-293. doi:10.1002/ajpa.1330830303

Revazov, A. A., \& Bolshakova, L. P. (1984). A medical genetic study of the turkmenistan population. IV. Analysis of the genetic compo- nent of fecundity variance in the Nokhur population. Genetika, 20, 1714-1718.

Spuhler, J. N. (1963). Natural selection. In J. V. Neel (Ed.), Genetic selection in man (pp. 1-111). Detroit: Wayne State University Press.

Spuhler, J. N. (1976). The maximum opportunity for natural selection in some human populations. In E. W. Zubrow (Ed.), Demographic anthropology: A quantitative approaches (pp. 185-226). Albuquerque: University of New Mexico Press.

Startseva, E. A., El'chinova G. I., Rassanov, V. P., Moshkina, I. S., Kadoshnikova M. I., \& Ginter, E. K. (1996). Genetic-demographic characteristics of highland Mari. Genetika, 32, 110-113.

Stelmachowska, B. (1963). Stowińcy i ich kultura. Poznań: Wydawnictwo Poznańskie.

Terrenato, L., Ulizzi, L., \& San martini, A. (1979). The effects of demographic transition on the opportunity for selection: Changes during last century in Italy. Annals of Human Genetics, 42, 785-797. doi:10.1111/j.1469-1809.1979.tb00671.x

Torrejon, J., \& Bertranpetit, J. (1987). Estructura biodemográfica de la problación del Valle de Camprodón. Trabajos de Antropologia, 20, 393-557.

Varte, R. L., \& Varte, R. Th. (2006). Natural selection intensity among the Hmar of Mizoram, India. Anthropologist, 8, 213-214.

Witt, W. (1933). Der Revecol und seine Umgebung in vor und frühgeschichtlicher Zeit, Delmanzosche Buchdruckerei, Stolp in Pommern.

Wokroj, F. (1958). Relikty ludności pomorskiej i nadbałtyckiej w świetle antropologii. w: Czlowiek w czasie i przestrzeni, 1, 99-102.

Wokroj, F. (1960). Relikty ludności słowiańskiej na Zachodnim Pomorzu. Prace i Materiaty Etnograficzne, 22, 102-104.

Wrzesińska, A., \& Wrzesiński, J. (2002). Rekonstrukcja zjawisk demograficznych dla serii wczesnośredniowiecznej populacji użytkującej cmentarzysko w Dziekanowicach. Studia Lednickie, 7, 63-75. 